\title{
A estrada de ferro de Bragança e a colonização da zona bragantina no estado do Pará
}

\section{The railroad of Bragança and the colonization of the Bragantina zone of the Para state}

Leonardo Milanez de Lima Leandro - Doutorando em Desenvolvimento Socioambiental (NAEA-UFPA).Email: leo.milanez@gmail.com

Fábio Carlos da Silva - Doutor em História Econômica; Professor Associado do NAEAUFPA. Email: fcsilva.ufpa@gmail.com

\section{Resumo}

O Pará foi o décimo terceiro estado do Brasil a ser percorrido por uma ferrovia. A Estrada de Ferro de Bragança foi inaugurada no dia 10 de junho de 1884. Concluídos os 229 quilômetros do eixo principal da via férrea, ligavam-se Belém e Bragança, feito celebrado com novo ato inaugural aos 4 de maio de 1908. Outros três ramais partiam do eixo principal em direção às colônias do Pinheiro, do Prata e de Benjamin Constant, que respectivamente saíam de Belém, IgarapéAçu e Bragança. Ao reunir informações a respeito da trajetória da empresa ferroviária, objetiva-se analisar o seu papel na formação da Zona Bragantina do estado do Pará, região cuja ocupação foi fomentada com vistas ao desenvolvimento de núcleos agrícolas no estado do Pará, no período de expansão da atividade gomífera.

\section{Palavras-chave}

Ferrovia. Colonização. Bragantina.

\begin{abstract}
Pará was the thirteenth State in Brazil to be traversed by a railway. The Railroad of Bragança was inaugurated in Brazil on June $10^{\text {th }}$ of 1884 . Concluded the 229 kilometers of the main axle, linked Belem and Bragança, celebrated with a new inaugural act on 1908 , may $4^{\text {th }}$. Others three branch lines starting of the main axle to the Pinheiro, Prata and Benjamin Constant colonies, and respectively leave from Belem, Igarape-Açu and Bragança. When to gather information respect to enterprise railroad trajectory, aim to analyze your part in the Bragantine Zone of the Para State formation, region whose occupation was fomented with the aim to development of agricultural core in the Para Estate, on the expansion rubber activity time.
\end{abstract}

\section{Keywords}

Railroad. Colonization. Bragantina. 


\section{INTRODUÇÃO}

A Estrada de Ferro de Bragança foi a décima terceira ferrovia inaugurada no Brasil, no dia 10 de junho de 1884. Concluídos os 229 quilômetros do eixo principal, com bitola de 1,00m, ligavam-se os municípios de Belém e Bragança, feito celebrado com novo ato inaugural aos 4 de maio de 1908. Outros três ramais, com bitola de $0,60 \mathrm{~m}$, partiam do eixo principal em direção às colônias do Pinheiro, do Prata e de Benjamin Constant, que respectivamente saíam de Belém, Igarapé-Açu e Bragança, três centros de convergência da produção dos núcleos populacionais da zona da estrada de ferro. O estudo analisa a trajetória da ferrovia na formação da Zona Bragantina, região cuja ocupação foi fomentada com vistas ao desenvolvimento de núcleos agrícolas no estado do Pará, no período de expansão da atividade gomífera.

No período em tela, três ferrovias foram construídas no Norte brasileiro: a Estrada de Ferro de Bragança, a Estrada de Ferro Madeira Mamoré e a Estrada de Ferro Tocantins. Os estudos existentes sobre estas ferrovias abordam preferencialmente o caso emblemático da Madeira-Mamoré, construída, após malogradas outras iniciativas no século XIX, através da empresa organizada pelo investidor norte-americano Percival Farquhar, ligando Porto Velho e Guajará-Mirim. A Estrada de Ferro Tocantins, construída para vencer o trecho encachoeirado do rio Tocantins, ligando Tucuruí e Jatobal, foi objeto de um relevante estudo, realizado pela historiadora Dulce Portilho Maciel (2011). As referências à Estrada de Ferro de Bragança, exceto o estudo realizado pelo historiador paraense Ernesto Cruz (1955), não a abordam como objeto central, espaço que ora ocupa.

A metodologia utilizada constou de levantamento bibliográfico, notadamente artigos, livros, monografias, dissertações, teses e algumas obras raras, e pesquisa documental: dados dos Censos de 1872 a 1920, dados do Anuário Estatístico do Brasil, Relatórios dos Presidentes da Província e Mensagens dos Governadores do Estado do Pará. Os documentos visualizados, especificamente os Relatórios/Mensagens dos Presidentes/Governadores do Pará, apresentam análises e relatos de ações e políticas com vistas a viabilizar o desenvolvimento agrícola na zona da Estrada de Bragança ${ }^{1}$ para o abastecimento do mercado

\footnotetext{
A distância que separa Bragança de Belém era percorrida majoritariamente pelo rio Guamá, a menor parte sendo percorrida por terra entre Bragança e Ourém. Desde a trilha aberta por Pedro Teixeira, ainda no século XVII, esse eixo de comunicação entre as duas cidades ficou conhecido como a Estrada de Bragança. Tal designação representa não apenas o eixo de comunicação entre Bragança e a capital, mas também o eixo de ligação entre Belém e os demais núcleos que estavam situados na direção de Bragança.
}

Novos Cadernos NAEA •v. 15 n. 2 • p. 143-174• dez. 2012 
regional, apontando a vinculação entre este projeto e a construção de uma via férrea que ligasse a zona produtora de alimentos com o porto de Belém. Tais relatos contrastam com aqueles focados no extrativismo da borracha, atividade de maior importância como internalizadora de recursos e rendas para o Estado, maior investidor da construção da ferrovia. A ferrovia, consumidora daquelas rendas nas constantes operações deficitárias, teve como fundamento econômico a criação de colônias agrícolas ao longo de seu eixo principal para produzir alimentos para o abastecimento do mercado da capital. Desse modo, os governantes se esforçaram e despenderam recursos para fomentar a colonização com o imigrante europeu, cuja suposta racionalidade das técnicas modernas no trato com a terra o capacitava a alavancar a produção de alimentos na Zona Bragantina.

A perspectiva de análise parte da premissa de que a ferrovia foi um projeto estruturante da política de colonização do território da Zona Bragantina. Por essa perspectiva, buscou-se verificar em que medida a trajetória da ferrovia bragantina - que ligava os centros produtivos de seu eixo ao porto exportador situado em Belém - pode apoiar a explicação da formação econômico-social da região. Os documentos a partir dos quais se aborda a história da referida ferrovia - por onde era transportada parte da produção dos núcleos populacionais - oferecem os registros e qualificações da contribuição dos centros produtivos e abastecedores do mercado de Belém, possibilitando a visualização de pontos dos trajetos percorridos pelas economias dos respectivos municípios.

Ao reunir informações a respeito dos principais eventos da trajetória da ferrovia, bem como os dados populacionais de municípios situados entre o rio Guamá e o oceano Atlântico, objetiva-se analisar o papel da ferrovia na colonização da Zona Bragantina do estado do Pará, especialmente durante as décadas finais do século XIX até as décadas iniciais do século XX.

O texto está organizado em quatro sessões: 1. Introdução. 2. A zona da Estrada de Bragança. 3. A trajetória da Estrada de Ferro de Bragança. 4. Apontamentos e considerações finais.

\section{A ZONA DA ESTRADA DE BRAGANÇA}

Localizada no nordeste do Estado do Pará, a área de influência da Estrada de Ferro de Bragança corresponde a um território de pouco mais de 30 mil quilômetros quadrados, limitado ao norte pelo oceano Atlântico, ao sul pelo rio Guamá, ao leste pelo rio Gurupi - que divide os estados do Pará e do 
Maranhão - e ao oeste com a baía do Marajó. Nas desembocaduras e no curso dos rios aí existentes e ao longo do litoral atlântico surgiram suas zonas pioneiras de ocupação.

Belém e Sousa do Caeté eram os centros administrativos das Capitanias do Grão-Pará e do Gurupy, respectivamente. Desde o rio Gurupi até a foz do rio Guamá, núcleos de catequese das ordens dos jesuítas e dos capuchinhos deram origem a alguns dos atuais municípios localizados na região: Cayté, Maracanã, Vigia, Curuçá, eram alguns dos 63 aldeamentos existentes no Pará até a primeira metade do século XVIII (MUNIZ, 1916). Desde a foz do rio Caeté, a saída para o Atlântico abria as possibilidades de comunicação entre Bragança e as localidades do litoral paraense, o Maranhão e outros estados do Nordeste brasileiro. Desde as cabeceiras do rio Caeté, depois por terra, chegava-se ao rio Guamá, por onde se navegava até Belém, a grande praça comercial do Norte brasileiro, o entreposto que se ligava aos altos cursos dos rios amazônicos bem como as principais rotas do comércio marítimo nacional e internacional.

A partir da segunda metade do século XVIII, as reformas promovidas na gestão de Mendonça Furtado, irmão do Marquês de Pombal, elevaram aqueles aldeamentos à categoria de vilas bem como promoveu a criação de novos núcleos populacionais. Como evidências da efetivação de tais atos administrativos podem ser enumeradas a fundação da vila de Ourém e da povoação de Tentugal, entre Ourém e Bragança, em 1753; as vilas de Cintra, Colares, São Caetano de Odivelas e Curuçá no ano de 1757; São Miguel do Guamá e Vizeu no ano de 1758 (ARAÚJO, 2003; BAENA, 1885). Neste período, por conta das disputas territoriais que colocaram a população indígena, já significativamente reduzida, sob a condição de cidadão português e também em função da criação da empresa monopolista Companhia Geral de Comércio do Grão-Pará e Maranhão, foi iniciado o comércio de trabalhadores africanos no Pará, e no porto de Bragança esses trabalhadores eram legalmente comercializados, ou contrabandeados do Maranhão (COUTO, 2003; ARAÚJO, 2003; CASTRO, 2006). Desde então, por resistência ao trabalho compulsório, outros núcleos populacionais foram formados pelos trabalhadores africanos e seus descendentes.

$\mathrm{Na}$ segunda metade do século XIX a comunicação terrestre definitiva entre as localidades da Zona Bragantina, importantes centros produtivos e exportadores de mercadorias comercializadas na praça de Belém, já havia sido estabelecida (PARÁ, 1873). Na porção central do território entre o rio Guamá e o oceano Atlântico o governo paraense levou a termo as experiências de instalação de colônias agrícolas a partir de 1875, ano de fundação da colônia de 
Benevides. É também nesse período que a balança comercial brasileira começou a experimentar a contribuição da fugaz economia da borracha.

A trajetória ascendente dos negócios da borracha vai entrar nas décadas de 1880 e 1890 em uma esplêndida fase de ampliação de seu alcance de mercado. Com o aperfeiçoamento do processo de vulcanização e a difusão do pneumático, utilizado em automóveis e bicicletas, a procura pela matéria-prima se expandiu de modo acelerado e a borracha passou a representar a matéria-prima de fundamental importância para a dinamização das economias industriais do final do século XIX e decênios subsequentes (PRADO JR., 2008). Em expansão acelerada, acompanhada da elevação contínua dos preços, a riqueza produzida pela borracha crescia na medida em que ascendia a procura pela matéria-prima quase que exclusiva do vale amazônico. Contraditoriamente, os negócios da borracha eram limitados pela disponibilidade de mão de obra, embora a contínua expansão seja recorrentemente explicada pelo incremento demográfico nos seringais, uma vez que as técnicas de extração do látex continuavam as mesmas (FURTADO, 2007).

O problema da mão de obra nos seringais era resolvido com o recrutamento de trabalhadores que já chegavam aos seringais endividados e forçados a um regime de trabalho mediante a servidão pela dívida. De outro modo, dirigiram-se para a região levas maciças de migrantes nordestinos, em função das secas ocorridas na região semiárida do Brasil em 1877-78 e 1888-89 (MUNIZ, 1916; CRUZ, 1955; ÉGLER, 1961; PENTEADO, 1967; SANTOS, 1980; BENCHIMOL, 2009). Todavia, nos anos imediatamente seguintes às referidas secas, os negócios da borracha apresentam pequenas retrações em relação aos anos anteriores ${ }^{2}$. Se os negócios da borracha atraíam a maior parte dos trabalhadores nordestinos que seguiram o rumo da Amazônia, alguma medida desses trabalhadores decidiu se estabelecer, ainda que temporariamente, nas colônias da Zona Bragantina ou em seringais aí existentes.

O abastecimento do seringal, que antes poderia ser considerado autossuficiente no tocante aos produtos básicos da alimentação (caça, pesca, pequenas criações, frutas e produtos agrícolas), passou a ser realizado a partir da importação de mercadorias (carnes, cereais, bebidas e conservas em geral). Era patente, portanto, a necessidade de criação de zonas produtoras de alimentos que ao menos aliviasse a pressão dos preços das mercadorias importadas, uma

\footnotetext{
Como os novos trabalhadores que chegavam aos seringais não dominavam a técnica da extração de látex e produção de borracha, provavelmente essas pequenas retrações possam ser explicadas pelo tempo de trabalho que os seringueiros mais experientes empreendiam na transmissão dos conhecimentos necessários para que os novos seringueiros alcançassem produtividade equivalente.
} 
vez que a maior parte dos trabalhadores do seringal, sob fortes esquemas de repressão da força de trabalho, era coibida de práticas de subsistência e forçada a se abastecer nos barracões dos seringalistas ${ }^{3}$. No caso da Zona Bragantina, os seringais existentes não contribuíam de modo significativo em relação a produção exportada ${ }^{4}$. Na safra de 1896-97, por exemplo, a produção dos municípios de São Caetano de Odivelas, São Miguel do Guamá, Vigia, Irituia, Ourém, Curuçá, Colares, Santarém Novo e Marapanim somadas correspondem a menos de 0,5\% da borracha produzida no Pará e exportada pelo porto de Belém (ALBUM, 1899). No período de 1900 a 1907, a produção gomífera da Bragantina oscilou entre $1,2 \%$ e $2,2 \%$ da produção total comercializada em Belém, que ainda era o maior dos tributários da produção da zona da ferrovia (PARÁ, 1910). Sendo assim, é provável que nos seringais da região os trabalhadores empreendessem outras atividades de subsistência no limite da capacidade de trabalho das unidades produtivas $^{5}$, com eventuais excedentes centralizados e comercializados no porto da capital.

Os presidentes da Província do Pará eram grandes entusiastas da ideia de construir uma ferrovia na Zona Bragantina e introduzir imigrantes estrangeiros a exemplo do que ocorria nas fronteiras do café brasileiro. Afastada da zona produtora de borracha, ainda que alguns de seus municípios produzissem uma fração da goma elástica exportada, o Estado fomentou a colonização através do recrutamento de imigrantes estrangeiros, notadamente europeus, em função de sua virtual capacidade de empreender técnicas modernas nas atividades agrícolas. Todavia, eram precárias as condições de acesso desde a Capital da Província à região, e o projeto para conectar Bragança e Belém seguia na esteira da onda que tomava conta das economias capitalistas no século XIX: as ferrovias. Com rendas suficientes para financiar tal empreendimento, não pouparam esforços, os governos, em realizar tal obra. Para que se tornasse objetiva a colonização europeia da Zona Bragantina, a ferrovia era a obra que viabilizaria o acesso rápido e fácil ao mercado da capital dos produtos agrícolas e matérias-primas industriais

3 Embora as práticas dos seringalistas fossem lesivas aos trabalhadores, explorando-os ao extremo e burlando suas contas correntes para que apresentassem saldos negativos, eram os seringalistas os responsáveis pela aquisição e colocação de mercadorias nos seringais. Aviar o trabalho no seringal era deveras custoso e com a expansão continuada dos negócios da borracha, cresciam também os custos do aviamento.

4 Há registros de produção de borracha para municípios localizados tanto no curso e na foz do rio Guamá quanto ao longo da costa atlântica. Daqueles são destacados São Miguel do Guamá, Ourém e Belém. Nas desembocaduras dos rios que correm para a costa e ao longo dela, enumeram-se Bragança, Quatipuru, Maracanã, Marapanim, Curuçá, São Caetano de Odivelas, Vigia e Colares.

5 Para a compreensão do conceito de capacidade de trabalho aqui referido ver a obra de Costa e seu debate sobre o "equilíbrio chayanoviano" (1995; 2000). 
com origem nas colônias modernas a serem criadas e situadas em seu eixo, bem como nas cidades e vilas já existentes. Tal investimento objetivava ainda melhorar as condições para o estabelecimento do transporte regular entre as colônias que se pretendia criar, dando ensejo às discussões sobre a construção de uma linha férrea que garantiria a efetiva ocupação das áreas atingidas pela mesma (PARÁ, 1874; ÉGLER, 1961).

As colônias de povoamento e produção agrícola na Zona Bragantina ganhariam, desse modo, maior dinamismo com a construção da ferrovia, com a qual o governo provincial explicou a necessidade de introdução da força de trabalho de origem europeia e o governo estadual insistiu no empreendimento, fomentando e organizando o serviço de colonização.

A marcha do povoamento não seguiria o rumo da ferrovia, nem tampouco a ferrovia determinaria essa marcha. Se a construção da ferrovia rumava para o leste, não era só nessa direção que seguia o fluxo de povoamento. Pelo contrário. Os núcleos foram abertos para esperar a ferrovia, não só na direção de Bragança, mas também na direção de Belém (PARÁ, 1879).

De modo resumido, considerando os dados organizados por Muniz (1916) e Cruz (1955) e os mapas elaborados por Penteado (1967), a intensificação da marcha do povoamento da Zona Bragantina teve início em 1875, com a instalação da colônia de Benevides. Em 1883, foi aberto o núcleo do Apehú, denominado Araripe, em 1886. Por ato de 1889 foi criada a colônia do Castanhal, emancipada no ano de 1893, quando também foi instalado o núcleo colonial de Marapanim, em seguida denominado Burgo Marapanim. Em 1894, o núcleo de Benjamin Constant, próximo de Bragança. Os núcleos de Jambuassú e Santa Rita do Caranã datam de 1895. Em 1897 foi a vez da Granja Américo. No ano posterior surgiram as colônias Ferreira Pena, Annita Garibaldi, José de Alencar e Santa Rosa. Ainda em 1898 foi criado o núcleo de Santo Antonio do Maracanã, oficialmente instalado em 1900 e recebendo o nome de Santo Antonio do Prata no ano de 1902. Os núcleos de Couto de Magalhães, Ianetama e Antonio Baena foram criados em 1899, este último depois incorporado ao núcleo de Annita Garibaldi. Até o ano de 1916, foram instalados núcleos coloniais situados na porção mais ao centro da Zona Bragantina. Os núcleos de Anhanga, onde antes fora o Burgo Marapanim, de São Luís e o de Augusto Montenegro, todos servidos diretamente pela ferrovia, foram criados entre 1901 e 1908, e até 1916 foram criados os núcleos da Estrada do Tentugal ou Capanema, de Pedro Teixeira e Iracema.

De acordo com dados organizados por Muniz (1916), de 1820 até 1889 entraram no Pará 18.173 pessoas consideradas imigrantes, sendo que 17.166 
eram nordestinos. Anote-se que o autor, em seus cálculos, considera a seca do biênio 1877-78 como o fenômeno de maior relevância para a ocorrência do fluxo migratório nordestino, uma vez que no período foi registrado o número de 13.300 pessoas, portanto, o contingente da ordem de $77 \%$ da imigração então anotada. Entre os anos de 1890 e 1916 os dados apontam um contingente de 53.440 pessoas imigrantes no Pará. Entre 1896 e 1900 os senhores Emilio Martins e Francisco Cepeda haviam introduzido 13.329 imigrantes (24,9\%), sendo que 193 destes foram recusados pelo serviço de colonização. No biênio 1915-16, registrou-se a entrada de 18.255 imigrantes (34\%), sendo que algo em torno de $38 \%$ desse número não chegou a dar algum resultado considerado aproveitável. Conforme explica Muniz (1916), entre os anos de 1902 e 1915 o governo estadual não contava com serviços organizados de imigração, ou seja, não são registrados contratos para a introdução de imigrantes. Desse modo, a análise apresentada pelo autor pode estar subestimada, uma vez que considera apenas os dados oficiais dos contratos de colonização e dos serviços de colocação de imigrantes organizado pelo poder público.

Vale lembrar que uma nova seca no biênio 1915-16 também concorreu para que as localidades abrigassem novo fluxo migratório de nordestinos (MUNIZ, 1916). Algumas destas localidades ainda floresceram nas margens da ferrovia, onde foram construídas estações ferroviárias, paradas ou estribos, constituindose em elementos centrais de núcleos produtores de gêneros diversos. No total, incluindo os ramais, a ferrovia bragantina tinha quarenta e seis pontos, entre estações, paradas e estribos. Da estação central São Braz, em Belém, até a estação de Bragança, existiam trinta e cinco pontos, sendo dezenove estações, quatro paradas e quatorze estribos ${ }^{6}$.

\subsection{A DINÂMICA POPULACIONAL DA BRAGANTINA}

Tomando como referência o documento Informações sobre as Comarcas da Provincia do Pará, organizado pelo diretor da $2^{\text {a }}$ Secção da Secretaria da Presidência

\footnotetext{
6 Seguindo as definições da publicação Ferrovias do Brasil, editada pelo IBGE (1948; 1956), as estações correspondem aos locais de parada dos trens com determinado nível de organização, onde existiam guichês para venda de passagens, abrigo para os passageiros, depósitos de mercadorias, desvios e, dependendo da categoria da mesma, poderia conter oficinas e abrigo para os carros; as denominadas paradas eram plataformas de embarque e desembarque de passageiros e mercadorias, e poderiam ter ou não um guichê para venda de passagens e área coberta; existiam ainda os estribos, construções simples de alvenaria ou madeira, utilizadas principalmente para o embarque e desembarque de mercadorias, e os postos telegráficos, estes últimos não presentes na Estrada de Ferro de Bragança.
}

Novos Cadernos NAEA •v. 15 n. $2 \cdot$ p. 143-174 • dez. 2012 
da Província, Manuel Baena (1885), observou-se, nas séries de dados dos Censos e do Annuário Estatístico do Brazil, a dinâmica populacional de dezessete municípios: Belém, Bragança, Vizeu, Quatipuru, Igarapé-Açu, Cintra, Maracanã, Marapanim, Salinas, Santarém Novo, Ourém, São Miguel do Guamá, Irituia, Vigia, Colares, São Caetano de Odivelas e Curuçá. O critério de escolha levou em consideração a compatibilidade entre as denominações dos municípios ou povoações que formavam as Comarcas localizadas entre o rio Guamá e a costa atlântica, desde Belém até Bragança, e as denominações presentes nas contagens de 1872 e de $1920^{7}$.

Por outro lado, tais localidades correspondem a núcleos de histórica ocupação com vistas à criação de empreendimentos para produção e exportação de diversos gêneros agrícolas e extrativos, estabelecidos nos séculos do Brasil Colonial e expandindo suas relações até a efetiva ligação possibilitada pela Estrada de Ferro de Bragança, no Brasil Republicano. No documento da Secretaria da Presidência, Belém, Bragança, Cintra, São Miguel do Guamá e Vigia constam como as sedes das respectivas Comarcas. Na contagem de 1872 não são apresentados dados sobre Marapanim, Maracanã e Igarapé-Açu. Entretanto, os dados sobre essas localidades aparecem nas contagens posteriores de 1890, 1900 e 1920, respectivamente. Apesar de Maracanã não ser citada nas contagens de 1872 e 1890, no documento de Baena (1885) aparece como localidade vinculada à Comarca de Belém. Por outro lado, uma lei estadual de 1897, devolveu o nome de Maracanã ao município chamado de Cintra, assim denominado por Mendonça Furtado. Igarapé-Açu, apesar de só aparecer na contagem de 1920, resultou do núcleo colonial Jambu-Assu, instalado no ano de 1895, como relacionado anteriormente. Cumpre lembrar, ainda, que as comarcas eram formadas pelas sedes dos municípios, e ainda freguesias, distritos e vilas, cujos dados discutidos correspondem a frações da dinâmica dos municípios enumerados.

Veja-se o que apresentam os dados dos Censos, em relação à evolução da população das localidades selecionadas da Zona Bragantina, área de influência da Estrada de Ferro de Bragança, o eixo para onde convergia a produção não só dos núcleos do seu leito, mas daqueles localizados no litoral paraense e nas margens do rio Guamá.

Embora atente-se para as imprecisões dos levantamentos realizados, não é objetivo deste estudo discutir tais distorções. Foge ainda do escopo deste estudo a análise das transformações políticas e administrativas que resultavam na criação e extinção de vilas, freguesias e municípios. 
Tabela 1. Evolução da população dos municípios selecionados.

\begin{tabular}{l|r|r|r|r|r}
\hline \multicolumn{1}{c|}{ Município } & 1872 & 1890 & 1900 & 1910 & 1920 \\
\hline Belém & 61,997 & 50,064 & 96,560 & 270,728 & 236,402 \\
\hline Bragança & 9,235 & 16,046 & 17,651 & 17,450 & 44,486 \\
\hline Vizeu & 4,125 & 6,639 & 8,911 & 13,516 & 15,823 \\
\hline Quatipuru & 1,744 & 1,929 & - & 10,405 & 20,642 \\
\hline Igarapé-Açu & - & - & - & 14,502 & 46,049 \\
\hline Cintra & 5,703 & 5,812 & - & - & - \\
\hline Maracanã & - & - & 7,439 & 10,469 & 18,472 \\
\hline Marapanim & - & 6,285 & 8,684 & 9,358 & 16,464 \\
\hline Salinas & 1,749 & 2,840 & 5,161 & 5,989 & 7,114 \\
\hline Santarém Novo & 1,021 & 1,987 & 3,770 & - & - \\
\hline Ourém & 1,881 & 2,886 & 3,980 & 4,619 & 7,370 \\
\hline São Miguel & 2,790 & 3,796 & 4,785 & 9,091 & 9,125 \\
\hline Irituia & 3,205 & 4,230 & 4,109 & 4,768 & 9,508 \\
\hline Vigia & 7,574 & 10,445 & 10,694 & 14,396 & 30,566 \\
\hline Colares & 3,018 & 1,315 & 1,710 & - & - \\
\hline São Caetano & 2,975 & 4,880 & 5,869 & 7,058 & 9,886 \\
\hline Curuçá & 6,440 & 6,097 & 7,197 & 8,496 & 13,919 \\
\hline Total & 113,457 & 125,251 & 186,520 & 400,845 & 485,826 \\
\hline
\end{tabular}

Fonte: Censos 1872-1920; Annuário Estatístico do Brazil 1908-1912.

Cumpre anotar que o espaço ao qual se atribui a população de Belém para as referidas contagens compreende um vasto território onde estavam incluídas algumas das colônias, estações e paradas ao longo da ferrovia, tais como Ananindeua, Benfica, Benevides, Santa Izabel, Americano, Apehú e Castanhal.

Da população estrangeira identificada pelo Censo de 1920, 17.847 pessoas estavam localizadas em Belém. Dessas, 194 estavam em Ananindeua, onde ficava localizada a parada do quilômetro 13 da ferrovia. Em Benevides, a primeira colônia ao longo do traçado da ferrovia, instalada em 1875, com imigrantes europeus, restaram 33 estrangeiros. Santa Izabel, núcleo colonial alcançado pelos trilhos da ferrovia em 1886, apresentou uma população de 44 estrangeiras. Em Americano, eram 55 indivíduos estrangeiros. Na localidade do Apehú, núcleo colonial criado em 1883, sem sucesso na instalação de açorianos e com fracasso repetido em 1886, foram identificadas 23 pessoas estrangeiras. Em Castanhal foram contabilizados 93 estrangeiros. Da população estrangeira identificada em Belém, 12.083 pessoas (67,7\%) eram de origem portuguesa, seguidas das de origem espanhola, contabilizadas em 2.903 pessoas (16,3\%). Foram identificados 
como italianos 781 indivíduos (4,4\%) e como turco-asiáticos 773 (4,3\%). Identificou-se ainda 245 ingleses $(1,4 \%)$ e 210 franceses $(1,2 \%)$. Os demais 852 indivíduos $(4,7 \%)$ eram estrangeiros de diversas nacionalidades

Bragança, município situado no outro extremo da ferrovia, nos termos das informações organizadas por Manuel Baena, era "uma das principaes cidades da provincia pela sua população, lavoura e riqueza do sólo" (BAENA, 1885, p. 3-4). Foi o maior produtor do fumo comercializado na capital no ano de 1896, conforme anotado no Album do Pará em 1899 (PARÁ, 1899), destacando-se ainda na produção e exportação de cereais, peixe, aguardente, algodão, e pelas fazendas de criação (PARÁ, 1908). Era ainda sede da Comarca de Bragança, que reunia os municípios de Quatipuru e Vizeu, estes também produtores de fumo, peixe, cereais, farinha, gado cavalar e bovino. No ano de 1920, os estrangeiros eram apenas 271 pessoas, na sua maioria de origem espanhola, contabilizados em 147 pessoas (54\%), que junto com os 103 portugueses (38\%), compunham a quase totalidade dos estrangeiros lá residentes. Foram identificadas ainda seis pessoas de origem turco-asiática, cinco ditas francesas e quatro italianas. Os demais imigrantes eram da Inglaterra, da Rússia e da Bolívia, sendo outros três de países diversos ou indeterminados.

Nas margens do rio Gurupi, fazendo divisa com o estado do Maranhão, Vizeu contabilizou, em 1920, 50 imigrantes estrangeiros, sendo 33 portugueses (66\%), 10 turco-asiáticos (20\%), dois alemães (4\%), um austríaco, uma espanhola, um boliviano, um peruano e um europeu de nacionalidade desconhecida.

Quatipuru, por sua vez, situado nas margens do rio de mesmo nome, registrou, na contagem de 1920, 111 pessoas de origem estrangeira. Em maior número eram os espanhóis, com 63 pessoas (56,7\%), seguidos dos turco-asiáticos com o contingente de 27 imigrantes $(24,3 \%)$. De outras nacionalidades foram identificados 14 italianos (12,6\%), duas cubanas, uma paraguaia, um grego e mais outras duas mulheres de nacionalidade desconhecida.

A Comarca de Cintra era formada pelos municípios de Cintra, Marapanim e Salinas, além da localidade de Santarém Novo. A partir da contagem de 1900, os dados apresentados com o nome de Maracanã, correspondem ao que seria a população de Cintra. Em 1920, a população de estrangeiros contabilizou 32 pessoas. Metade era de origem portuguesa, 11 eram da Turquia Asiática (34\%), uma de origem suíça, um dito italiano, um inglês, um espanhol e um francês. $\mathrm{Na}$ população de Salinas, para o ano de 1920, estão incluídos 13 indivíduos estrangeiros: dez eram portugueses e três eram turco-asiáticos.

São Miguel do Guamá era sede da Comarca do Guamá, formada ainda pelos municípios de Ourém e Irituiua. Dos municípios da Zona Bragantina, era 
o segundo maior tributário da produção de borracha comercializada na capital (PARÁ, 1899; PARÁ, 1910). Era reconhecido ainda pela produção e exportação de tabaco, conforme anotado por Baena (1885) e Augusto Montenegro (PARÁ, 1908). Na população registrada em 1920, 118 pessoas eram estrangeiras. A grande maioria $(89,8 \%$ ) era de origem portuguesa e os outros 12 restantes eram sete da Turquia Asiática, três da Espanha e dois de nacionalidade desconhecida.

No ano de 1920, da população do município de Ourém, foram identificados 65 estrangeiros, dos quais 59 eram portugueses (90,7\%), dois italianos, um inglês, uma francesa, um estadunidense e um turco-asiático.

O município de Irituia, que segundo as informações de Baena (1885), de Paes de Carvalho (1899) e de Augusto Montenegro (1908) era o centro produtor de tabaco de excelente qualidade e muito apreciado na capital, destacava-se também pela produção de borracha. Na safra de 1896-97, o município foi o quarto maior produtor do fumo comercializado na capital e o quarto maior produtor de borracha da Zona Bragantina (PARÁ, 1899). A contagem populacional de 1920 registrou o contingente de 91 estrangeiros, sendo 87 de origem portuguesa, dois espanhóis, um argentino e um turco-asiático.

Os municípios de Vigia, Colares, São Caetano de Odivelas e Curuçá compunham a Comarca da Vigia. Em Vigia, o Censo de 1920 contabilizou 61 indivíduos estrangeiros. Mais da metade era de origem portuguesa (32 pessoas). Os demais europeus eram cinco franceses, um espanhol e um italiano, havendo, ainda 11 turco-asiáticos, cinco uruguaios, quatro bolivianas e mais outros dois imigrantes de nacionalidades desconhecidas.

São Caetano de Odivelas, conforme relatou Baena (1885), era um dos pontos de escala das linhas de navegação costeira subvencionadas pelo governo e exportava para o mercado da capital farinha, peixe, ostras, bananas, abacates e laranjas. Já se comentou que os municípios da Zona Bragantina não eram dos mais significativos produtores de borracha. Contudo, na safra de 1896-97, foi o município de São Caetano de Odivelas o que mais contribuiu, em relação aos demais da região, produzindo 13.216 arrobas (PARÁ, 1899). No ano de 1920 eram dez estrangeiros incluídos na população, sendo nove portugueses e um turco-asiático.

Da Comarca da Vigia, cumpre registrar ainda o município de Curuçá, que assim como São Caetano de Odivelas, era produtor de borracha e ponto de escala das linhas de navegação subvencionadas, que transportavam para a capital farinha, milho, peixe, arroz, aves, porcos e frutas (BAENA, 1885; ALBUM, 1899; ALBUM, 1908). No ano de 1920, o Censo registrou o contingente de 21 pessoas estrangeiras. Eram dez pessoas de origem portuguesa e oito pessoas foram identificadas como turco-asiáticos. Havia ainda dois espanhóis e um francês. 
Igarapé-Açu não é citado nos Censos anteriores ao de 1920. Todavia, resulta do núcleo de Jambu-Assu, criado no ano de 1895. De acordo com os dados levantados por Muniz (1916), eram 1.806 os colonos aí localizados no ano de 1900, sendo 647 espanhóis, 10 portugueses e 1.149 brasileiros. No recenseamento dos núcleos coloniais realizado em 1901, foram contabilizadas 1.980 pessoas. A colônia foi elevada à categoria de município em 1906. O Annuario Estatistico do Braz̧il calculou a população para o ano de 1907 em 13.926 habitantes, chegando a 14.502 pessoas no ano de 1910. Em 1920, o Censo apresenta o número de 46.049 habitantes no município, aí incluídos 384 estrangeiros. Das nacionalidades, eram 141 turco-asiáticos (36,7\%), 123 portugueses (32\%), 100 espanhóis (26\%), 12 italianos (3\%), 3 estadunidenses, 1 alemão, 1 francês, 1 grego, 1 polonês e 1 de nacionalidade desconhecida.

O recenseamento de 1920 ainda relacionou 26.907 estabelecimentos rurais no Pará, dos quais mais da metade estava localizada na Zona Bragantina: eram 15.191 estabelecimentos (56,5\%). Nesses estabelecimentos trabalhavam pouco mais que $2 / 4$ da população paraense com atividades vinculadas à exploração do solo (agricultura, criação, caça e pesca), sendo que 1/4 estava localizado nos estabelecimentos de Belém, Igarapé-Açu e Bragança, onde também estavam localizados os maiores contingentes absolutos da população estrangeira dos municípios selecionados. Note-se que correspondem às principais cidades servidas pela ferrovia, respectivamente seus trechos de onde seguiam os ramais do Pinheiro, do Prata e o de Benjamin Constant. Em Belém foram recenseados $4.541(16,9 \%)$ estabelecimentos, onde trabalhavam, em atividades vinculadas a produção de alimentos, 28.181 pessoas na agricultura, 103 na criação de animais, havendo ainda outras 1.256 pessoas realizando atividades de caça e pesca. Igarapé-Açú foi o segundo município com maior número desses estabelecimentos, apresentando 4.116 unidades produtivas (15,3\%) com 11.233 pessoas atuando na agricultura, 19 na criação de animais e 1 nas atividades de caça e pesca. Em seguida estava Bragança, com 3.184 estabelecimentos (11,8\%), onde 8.897 pessoas trabalhavam na agricultura, 16 atuavam na criação de animais e outras 688 caçavam e pescavam. Cumpre anotar que dos outros 3.350 $(12,5 \%)$ estabelecimentos rurais recenseados nos municípios selecionados, onde trabalhavam 50.247 pessoas entre agricultores, criadores, pescadores e caçadores, 951 estavam localizados em Quatipuru (3,5\%), 492 em Vigia (1,8\%), 371 em São Miguel do Guamá (1,4\%), 340 em Maracanã (1,3\%), 321 em Marapanim (1,2\%), 289 em Irituia (1,1\%), 198 em São Caetano de Odivelas (0,74\%), 186 em Ourém (0,69\%), 159 em Salinas (0,6\%) e 43 em Vizeu (0,2\%). 
Passado em revista o quadro geral da formação econômico-social da Zona Bragantina, qualificado o caráter geral da constituição da população e dos gêneros produzidos pelos núcleos, e apontadas questões relacionadas à concepção do projeto ferroviário, avança-se à análise dos principais eventos relacionados à contratação da empresa, organização, construção e gestão da ferrovia, bem como alguns dos impactos socioeconômicos e ambientais decorrentes da implantação da mesma na Zona Bragantina do estado do Pará.

\section{A TRAJETÓRIA DA ESTRADA DE FERRO DE BRAGANÇA}

As primeiras iniciativas para a construção de uma ferrovia que conectasse Belém e Bragança, na época dois importantes centros dinâmicos da socioeconomia paraense, decorrem do ano de 1870, quando uma lei provincial autorizou o governo paraense a contratar uma empresa que levasse a termo tal empreendimento (VIEIRA, 1954). No ano de 1874 foi sancionada a Lei n. 809, que concedia privilégios a uma empresa que construísse uma estrada de ferro entre Belém e Bragança e estabelecesse colonos ao longo de seu eixo (MUNIZ, 1916; CRUZ, 1955).

Com o regulamento da referida lei, foi celebrado um contrato com o senhor Cícero Pontes, residente no Rio de Janeiro e procurador do senhor Antonio Gonçalves da Justa Araújo, residente no Ceará, para a construção de uma estrada de ferro, inclusive com ramais previstos para ligar a estrada principal às localidades do Pinheiro, Vigia, Cintra, Ourém e São Miguel do Guamá, concedendo direitos de exploração durante quarenta anos, remunerando-se o capital a juros de 7\%. O contrato previa ainda a introdução de dez mil colonos em famílias, garantindo-se, nos termos da lei, o reembolso das despesas realizadas (PARÁ, 1875).

Entretanto, passados 17 meses da celebração do primeiro contrato e faltando um mês para caducar, não constava que nenhuma atividade houvesse iniciado em relação à via férrea (PARÁ, 1876). O concessionário jamais executou atividade alguma daquelas contratadas e não foram encontrados indícios do pagamento das multas contratuais previstas. Com o contrato rescindido e aberto novo processo concorrencial, até março de 1878 o governo provincial ainda não havia recebido novas propostas (PARÁ, 1878).

No ano de 1879, novo contrato de construção foi celebrado com o procurador dos senhores Izidro Borges Monteiro e Francisco da Siqueira Queiroz, concessionários da Estrada de Ferro Bragantina, em São Paulo. O novo contrato não seguira a risca o dispositivo legal que regulava os serviços 
ferroviários, especificamente no que concerne à instalação de colonos, uma vez que à Província afluía grande contingente de nordestinos. Por outro lado, enfrentava dificuldades para efetuar o reembolso das despesas com a imigração estrangeira. Desse modo, foi suprimida a cláusula que previa a instalação de núcleos coloniais ao longo de seu eixo principal (PARÁ, 1879). Contudo, tal contrato, como o anterior, não seria cumprido (CRUZ, 1955).

Sem que os interessados a quem foram concedidos os direitos de exploração do serviço ferroviário tomassem qualquer iniciativa ou realizassem qualquer obra no sentido de tornar objetiva a via férrea entre a capital da Província, Belém, e a cidade de Bragança, o governo provincial manteve acesa a chama que alimentava o desejo de levar a termo tal empreendimento. Uma década de negociações frustradas havia transcorrido e os administradores da Província continuavam a insistir naquilo que seria um importante elemento para dinamizar a socioeconomia paraense: a ferrovia bragantina.

Foi em fevereiro de 1883 que chegou à Província do Pará o senhor Bernardo Caymari, incumbido de negociar as bases de um contrato para a construção da ferrovia. Em ofício do dia 6 de fevereiro daquele ano, o senhor Bernardo Caymari apresentou ao presidente provincial a procuração que o habilitava como representante da Companhia Estrada de Ferro de Bragança, constituída pelos senhores Ambrósio Leitão da Cunha, Miguel Calógeras e Otto Simon, e sediada no Rio de Janeiro. Desde então, o procurador da Estrada de Ferro de Bragança reclamou as bases do contrato anterior para encetar os trabalhos de construção da via férrea. Entretanto, o contrato celebrado no ano de 1879 ainda estava em voga, e até que caducasse ou até que os concessionários anteriores expressassem desistência, nenhum trabalho poderia ser autorizado (PARÁ, 1883).

\subsection{A CONSTRUÇÃO DA FERROVIA}

Curiosamente, a lógica em relação ao desejo de materialização da ferrovia foi invertida. Se até então eram os administradores da Província os mais interessados em levar a termo a obra, embaraçada pelos concessionários, agora eram os pretendentes a concessionários os mais interessados, cujo maior embaraçador era a estrutura burocrática da administração provincial.

Apesar disso, em junho de 1883 foi celebrado o contrato, levantado o capital exigido pela Província e iniciada a construção. Teve início a materialização da tão sonhada obra. Com ela, tantos benefícios eram esperados que os primeiros trilhos foram assentados numa solenidade pública, com a participação da elite política da Província do Pará, da diretoria da empresa e demais cidadãos. Tal era 
a magnitude do ato, que da cerimônia participou "o que Belém possuía de mais representativo, nos diferentes círculos social, econômico e político" (CRUZ, 1955, p. 67). Representa ainda a grandeza deste ato a colocação dos primeiros trilhos, assentados sobre dormentes de mármore e fixados com oito pregos de bronze (CRUZ, 1955).

Quando foi iniciada a construção da ferrovia a primeira colônia agrícola da estrada de Bragança, Benevides, já havia completado oito anos de existência. Instalada no ano de 1875 e distando de Belém 29 quilômetros, recebeu 180 imigrantes de diversas nacionalidades: 87 franceses, 35 italianos, 33 espanhóis, 11 alemães, 5 belgas, 3 ingleses, 3 suíços, 2 argentinos e 1 estadunidense. Contudo, as condições precárias de comunicação com centros urbanos e para o escoamento da produção impuseram a parte dos colonos seu deslocamento para a capital. Em começo de 1877, havia entrado na colônia 364 colonos e saído 247. Das 117 pessoas restantes 71 eram de origem francesa, 10 eram ditas italianas, 2 ditas espanhola, 3 ditas belgas, 4 ditas suíças, 1 dita portuguesa e outros 26 colonos eram brasileiros (MUNIZ, 1916; CRUZ, 1955; PENTEADO, 1967).

O esforço de localizar imigrantes europeus na colônia, sem oferecer os resultados esperados, foi compensado pelo afluxo de nordestinos em direção à Amazônia em função da seca ocorrida no semiárido nordestino entre os anos de 1877 e 1878. Com esse fenômeno em curso, no ano de 1878 foram nomeadas comissões encarregadas de socorrerem aos migrantes nordestinos, regulamentado o serviço de assistência aos retirantes e encaminhados trabalhadores para os núcleos de Benevides, Santa Izabel, Tentugal e no caminho de Vigia (MUNIZ, 1916).

Relatou-se estarem localizados cerca de 800 cearenses no ano de 1878, ascendendo ao número de 9.000 no ano de 1879 (PARÁ, 1878; PARÁ, 1879). Acrescente-se que em 1881, de acordo com as informações reunidas por Manuel Baena, este núcleo colonial chegou a contabilizar 12.000 mil pessoas, em função daquela estiagem prolongada por que passava o semiárido brasileiro, quando parte dos nordestinos emigrados chegaram à Província (BAENA, 1885).

Pouco mais de um ano havia transcorrido desde a cerimônia de assentamento dos primeiros trilhos e uma nova solenidade marcou a inauguração do primeiro trecho da Estrada de Ferro de Bragança. Celebrava-se a abertura do tráfego regular dos primeiros 29 quilômetros da ferrovia, ligando Belém à colônia de Benevides. Segundo Cruz (1955, p. 75), a Zona Bragantina iniciava sua contribuição para "uma nova era de progresso para a economia paraense, e para o desenvolvimento agrícola de uma região ainda inexplorada e desconhecida, porém de grande futuro". Nessa solenidade, onde estiveram presentes, mais 
uma vez, o "que a cidade de Belém tinha de mais representativo nas esferas administrativa, social e política” (CRUZ, 1955, p. 75), foram concedidas vinte cartas de alforria a escravos na colônia.

Outro acontecimento contribuiria para marcar essa data tão importante: ao chegar nas proximidades de Ananindeua, o trem que retornava com os demais convidados da cerimônia de inauguração para Belém descarrilou. Apesar do transtorno, não ocorreram graves danos aos passageiros e em poucos dias o trânsito foi restabelecido dentro da normalidade. Durante os dois meses finais do ano de 1884, os resultados financeiros apresentados pela ferrovia já indicavam aquele que foi o seu comportamento predominante: as operações deficitárias. No levantamento realizado por Cruz (1955), a movimentação de passageiros transportados foi da ordem de 2.624 pessoas. As operações dos meses finais de 1884 importaram numa receita de 8:385\$020 (oito contos e trezentos e oitenta e cinco mil e vinte réis), enquanto a despesa importou na quantia de 18:405\$740 (dezoito contos e quatrocentos e cinco mil e setecentos e quarenta réis), dando um resultado deficitário da ordem de 10:020\$720 (dez contos e vinte mil e setecentos e vinte réis).

Ao mesmo tempo em que foi iniciada a construção da ferrovia, em 1883, buscou-se, sem sucesso, instalar imigrantes açorianos no núcleo do Apehú (CRUZ, 1955). Em março de 1885 o tráfego da estrada de ferro já alcançava pouco mais de 40 quilômetros e até novembro foram entregues ao tráfego público quase 60 quilômetros, aproximando-se das terras do Castanhal e tocando as colônias de Benevides, Santa Izabel e Apehú. Quando a ferrovia já tinha alcançado e trafegava com regularidade até o núcleo, ocorreu nova tentativa de instalação de 21 famílias desses imigrantes que novamente não chegou a se efetivar em função das condições gerais da localidade, que não correspondiam àquelas que versavam o contrato da colonização (MUNIZ, 1916). Segundo João Antonio Henriques, os imigrantes "aterrorisaram-se com a vista da floresta virgem, de arvores seculares, [...] e resolveram voltar para a cidade, nem siquer ali apeando-se dos wagons" (PARÁ, 1886, p. 52).

\subsection{A ESTATIZAÇÃO DA ESTRADA DE FERRO DE BRAGANÇA}

Nos três anos iniciais a construção da ferrovia avançou com uma média de 20 quilômetros anuais. Após esse período, os recorrentes déficits nas operações impuseram aos concessionários a rescisão do contrato, sendo a estrada encampada pela Província ainda em 1886. A encampação foi autorizada pela Lei Provincial n. ${ }^{\circ} 1.292$, de 13 de dezembro de 1886, levada a termo em 31 de dezembro pelo 
preço de 1.500:000 $\$ 000^{8}$ (um mil e quinhentos contos de réis), em apólices, resgatáveis ao fim de 12 anos, com juros de 6\%. Sob a tutela do Estado, a ferrovia agora seguiria uma marcha irregular até sua conclusão (PARÁ, 1887).

Incorporada à estrutura burocrática da Província, a ferrovia não avançou na direção de Bragança. Visando atender à elite comercial, importadora e exportadora de produtos, sujeita às despesas extras com o transporte de mercadorias que chegavam até a estação de São Braz, a obra recuou em direção ao centro comercial de Belém (VIEIRA, 1954; CRUZ, 1955). Nesse período a estação central de São Braz foi erguida e inaugurada em maio de 1893.

Só no ano de 1889 é que são retomadas iniciativas no sentido de dar prosseguimento à obra projetada para conectar Belém e Bragança. Após a autorização concedida pelo Governo Geral e expedidas as ordens à tesouraria da fazenda provincial na importância de 800:000\$000 (oitocentos contos de réis), foram retomados os trabalhos para o prolongamento da ferrovia, sob a inspeção e direção da comissão incumbida da recepção e colocação de migrantes cearenses nas margens da estrada de Bragança. A comissão designada para tanto, era composta por engenheiros da Província, o mestre de linha da ferrovia e outros agentes da seção de obras públicas. Havia ainda a orientação de aproveitar, na tarefa, os trabalhadores localizados nas colônias do Araripe e Benevides e outros que estivessem recebendo socorros públicos. Aos que se negassem a realizar os trabalhos, tanto os localizados nas colônias quanto outros que recebessem os socorros públicos, tal apoio seria cessado (PARÁ, 1889). Vê-se, pois, evidenciada a forma como o Estado exerceu, com a política de colonização, controle da força de trabalho dos imigrantes na Zona Bragantina.

A estrutura burocrática do governo brasileiro transitava da monarquia para a república e o Pará era governado provisoriamente pelo capitão-tenente Duarte Pinto Guedes. Conforme consta no relatório com o qual passou a administração do estado do Pará ao governador Lauro Sodré, a estrada de ferro foi prolongada em mais três quilômetros, até a localidade chamada Chermont, cujo trecho havia sido aberto ao tráfego em 25 de dezembro de 1890 (PARÁ, 1891). Sem maiores explicações sobre os trabalhos nem das condições gerais de tráfego, Lauro Sodré comentou que no ano de 1894 a Estrada de Ferro de Bragança contava com 75 quilômetros de extensão, agora passando de Castanhal e levando a estrada até Marapanim, e que entre 1890 e 1897 a estrada tinha sido ampliada em

\footnotetext{
Segundo Cruz (1955), o valor da operação correspondeu a 1.800:000\$000. Entretanto, conforme explicou o presidente da província, Joaquim da Costa Barradas, responsável por levar a termo a decisão da Assembléia Provincial, considerando os mesmos estudos aos quais se refere Cruz (1955), o resgate da ferrovia foi efetuado ao preço de 1.500:000\$000, "menos 300 contos do que tentára o sr. Conselheiro Tristão de Alencar Araripe” (PARÁ, 1887, p. 5).
}

Novos Cadernos NAEA •v. 15 n. $2 \cdot$ p. 143-174 • dez. 2012 
37 quilômetros, no entanto, sem revelar onde se encontrava seu ponto extremo (PARÁ, 1897). Foi ainda no ano de 1894 que teve início a obra do ramal do Pinheiro, inaugurado em 1906, com 27 quilômetros (VIEIRA, 1954).

A mensagem do governador Paes de Carvalho, em 15 de abril de 1898, informa que a ferrovia contava com 105 quilômetros de tráfego aberto (PARÁ, 1898). O extremo até a referida data era a estação de Jambu-Assu (CRUZ, 1955; PENTEADO, 1967), local onde foi criada uma colônia em 1895 e cuja introdução de colonos foi realizada, por contrato com o Governo Estadual, pelos senhores Francisco Cepeda, Heliodoro Jaramillo e Emilio Martins (MUNIZ, 1916). Daí partia o ramal do Prata, na extensão de 20 quilômetros.

A Estrada de Ferro de Bragança, como já apontado, operava sempre em regime deficitário, o que provocava constantes reclamações dos administradores estaduais, dando ensejo a debates sobre a possibilidade do arrendamento da ferrovia para saldar as dívidas (PENTEADO, 1967). Por outro lado, os mesmos homens públicos insistiam em afirmar que ela seria um importante elemento para dinamizar a economia da zona sua zona de influência, uma vez que nela seriam produzidos, pelos colonos, os gêneros que abasteceriam a capital. A marcha de avanço da ferrovia havia diminuído seu ritmo. Dos 20km/ano, nos primeiros anos, passou a $7 \mathrm{~km} /$ ano, agora já com cerca de quinze anos de operação. Entre os anos de 1897 e 1901 foram construídos mais 31 quilômetros, chegando ao núcleo onde estava situada a parada do Livramento (CRUZ, 1955).

Quando Augusto Montenegro assumiu o governo do estado do Pará, incorporou a conclusão da ferrovia em seu programa de governo (PARÁ, 1902; PARÁ, 1908). Afastando a possibilidade de arrendamento e lançando mão da prerrogativa constitucional de poder realizar empréstimos no exterior, o governador levantou capital $£ 650.000$ (seiscentos e cinquenta mil libras) junto ao banco Seligman Brothers, em Londres, para concluir a obra, reformar alguns trechos, construir novas estações e realizar outros melhoramentos (PARÁ, 1917). De fato, desde sua eleição, em 1901, até sua saída, em 1908, o governador se propôs a levar a termo tal empreendimento e no último ano de sua administração, entregou ao estado do Pará a Estrada de Ferro de Bragança, com os ramais ligavam, respectivamente, os municípios de Belém, Igarapé-Açu e Bragança às colônias do Pinheiro, do Prata e de Benjamin Constant. Este último teve a construção contratada em 1900 e concluída em 1904, com extensão de 26 quilômetros. Finalmente, Belém e Bragança poderiam manter comunicação direta por uma via férrea.

Foi no último ano do governo de Augusto Montenegro que as obras da ferrovia avançaram com maior velocidade na direção de Bragança, alcançando a 
cidade em abril de 1908 e inaugurada em maio do mesmo ano. Estava concluído o eixo de convergência ao qual se ligavam os núcleos populacionais existentes na zona de produção de alimentos para o abastecimento da capital e seus seringais. Tais núcleos correspondem aos resultados das tentativas de instalação de colônias agrícolas com a introdução de imigrantes estrangeiros, além daqueles núcleos historicamente erguidos com vistas ao desenvolvimento dos empreendimentos coloniais. Todavia, era de origem nordestina e paraense a maior parte dos trabalhadores localizados nas colônias criadas para a instalação dos europeus.

\subsection{A CRISE ECONÔMICA E A FERROVIA PÚBLICA NO VERMELHO}

Com o ingresso da borracha com origem na Ásia tropical no mercado mundial, a expansão dos negócios da borracha amazônica chegava ao seu limite. Ao invés das soluções tecnológicas que viabilizaram os seringais asiáticos de alta produtividade, os números crescentes na tonelagem de borracha exportada até a década de 1930 podem ser explicados pela contribuição de novas zonas produtoras na Amazônia. Por outro lado, a queda geral dos preços, com o aumento da mercadoria disponível no mercado mundial, resultou no colapso da economia do aviamento. Nesse ponto, a zona agrícola objetivada pelas colônias ao longo do eixo da ferrovia atravessava uma trajetória ascendente quando são observados o aumento do tráfego regular da ferrovia e o crescimento das rendas com o transporte dos gêneros da lavoura para o abastecimento regional.

Encerrada a construção, o desenvolvimento do tráfego da ferrovia implicava em manutenção e melhoramentos para o seu bom funcionamento, uma vez as operações lucrativas principiavam a dar sinais. Para que atendesse seu objetivo de escoadouro de produtos da lavoura e operar em regime superavitário, João Coelho, sucessor de Augusto Montenegro no governo estadual, alertou a necessidade de exercer fiscalização na arrecadação e de prolongar a via principal em direção ao Maranhão (PARÁ, 1910).

Como necessitava de constantes aportes do tesouro estadual para saldar os compromissos, o governador promoveu uma reforma administrativa na empresa ferroviária. Com a reforma, de tal modo ocorreu uma redução nos custos operacionais que, pela primeira vez na história de funcionamento daquelas locomotivas, a empresa operou, nos cinco meses finais do ano de 1910, sem necessitar de suprimentos do tesouro para remunerar seu pessoal ordinário (PARÁ, 1911). Mesmo assim, isso não significou o início de operações lucrativas.

Estas começaram a ser registradas a partir do ano de 1915. Na mensagem dirigida ao Congresso Legislativo no dia 1 de agosto daquele ano, o governador 
Enéas Martins informava que as ações levadas a termo pela direção da ferrovia resultariam na eliminação das operações deficitárias, uma vez que a empresa não tinha mais débitos a serem saldados com aportes do tesouro público, bastando, para tanto, as rendas próprias arrecadas (PARÁ, 1915). Por outro lado, o resultado do ano de 1915 ainda apresentou um déficit de 56:156\$249 (cinquenta e seis contos e cento e cinquenta e seis mil e duzentos e quarenta e nove réis), uma diferença de pouco menos do que 700:000\$000 (setecentos contos de réis) em relação ao déficit do exercício de 1914 (PARÁ, 1916).

Desde que foi incorporada a estrutura burocrática do governo do Pará, em 1886, a Estrada de Ferro de Bragança apresentou o melhor resultado operacional, em termos absolutos, em 1915. Se naquele ano o déficit era de 86:498\$015 (oitenta e seis contos e quatrocentos e noventa e oito mil e quinze réis), trafegando os cerca de 60 quilômetros que separavam Belém e a colônia do Apeú, descia a pouco mais de 56:000\$000 (cinquenta e seis contos de réis) em 1915, trafegando por toda sua extensão, desde Bragança até Belém. Dessa maneira, no seu último ano de governo, Enéas Martins considerava patente o desaparecimento do déficit da ferrovia. O primeiro resultado anual lucrativo foi realizado no exercício de 1916.

No ano seguinte, em 1917, Lauro Sodré, ao retornar ao cargo mais elevado do executivo estadual, sucedendo Enéas Martins, também colocou a ferrovia como parte integrante de seu programa de governo. Planejava prolongar os trilhos até o estado do Maranhão e construir ramais em demanda dos municípios do litoral (PARÁ, 1917). A organização do tráfego e fiscalização das rendas havia surtido bons resultados. As rendas se elevaram ainda em função de reajustes em passagens e fretes e outras reformas operacionais, como a transferência de carros de trechos menos rentáveis para aqueles mais dinâmicos?.

Se por um lado a ferrovia apresentava os primeiros resultados, nos quais a soma das receitas foi mais elevada que as somas das despesas, e o projeto do prolongamento da via férrea até o Maranhão integrava o programa do novo governo, por outro, o governador, que desde o século XIX defendia o prolongamento da ferrovia até o estado vizinho, antecipava o mecanismo que resultaria na sua extinção. É que uma rede de estradas de rodagem já servia de ligação entre o eixo ferroviário e os municípios litorâneos para os quais se planejou construir ramais. Todavia, com o arrefecimento dos negócios da borracha, o tesouro público não dispunha de recursos para encetar os estudos necessários à construção dos ramais, e enquanto a realização dos ramais da estrada de ferro na

9 Arquivo Público do Estado do Pará, Fundos da Secretaria do Governo, Série Ofícios, Ofícios da Estrada de Ferro de Bragança, Caixa 163. 
direção das cidades do litoral não fosse completada, o governador sinalizou para a organização e o estabelecimento regular do tráfego nessas estradas, como as que já alcançavam Vigia, Curuçá e Maracanã (PARÁ, 1917).

Enquanto apresentava seu melhor resultado financeiro, tinham início os estudos e negociações que resultaram na aquisição da ferrovia pelo Governo Federal, uma operação que visava dar novo vigor à situação financeira do Pará, face à crise econômica causada pelo aviltamento do preço da borracha. As negociações envolviam ainda o seu arrendamento ao governo estadual. Apesar dos anos de operação lucrativa, as rendas não eram suficientes para realizar os serviços de manutenção da via e a operação de venda ao Governo Federal visou captar recursos para promover tais serviços. A venda da ferrovia foi realizada em duas parcelas, uma no valor de 5.000:000\$000 (cinco mil contos de réis) e outra no valor de 12.000:000\$000 (doze mil contos de réis). O pagamento da parcela de 12.000:000\$000 (doze mil contos de réis) ocorreu em agosto de 1923, mediante a emissão de doze mil apólices da dívida pública, no valor de 1:000\$000 (um conto de réis), a juros de 5\%, ultimando assim a operação de venda ao governo federal. O pagamento dos 5.000:000\$000 (cinco mil contos de réis), quantia contratualmente destinada à reparação da ferrovia, foi sustado até a conclusão da avaliação do material rodante e pago apenas em 1926 (BRASIL, 1924; BRASIL, 1925; PARÁ, 1926).

Nos anos seguintes, conforme estabelecia o contrato de arrendamento da ferrovia, a obra de recuperação foi realizada, minimizando os riscos de acidentes e dando ensejo a discussões referentes a possibilidade de reaquisição da Estrada de Ferro de Bragança pelo governo estadual, uma vez que a ferrovia atravessou um período de operações lucrativas. Por outro lado, a ferrovia retornava ao seu padrão deficitário, não revertendo a regra de que o Estado deveria recorrentemente lançar mão de suas economias para atender as necessidades de conservação.

Nesse ponto, no início da década de 1930, uma rede com cerca de 400 quilômetros de vias terrestres já existia e ultimava as novas transformações que iriam ocorrer no sistema técnico de transporte na Bragantina. Dessa forma, o governo paraense decide por fim aos problemas que a estrada acarretava aos cofres públicos e em 1936 devolveu a ferrovia ao Governo Federal, passando a Estrada de Ferro de Bragança definitivamente a integrar a rede ferroviária nacional.

Sem que a ferrovia novamente voltasse a oferecer lucros, tornou-se impraticável a conservação da via e manutenção das locomotivas e vagões. Dessa forma, o relatório do Ministério dos Negócios da Viação e Obras Públicas, a julgar o relato do diretor da ferrovia para o exercício de 1945-1946, considera a estrada em "estado de decomposição" (BRASIL, 1946, p. 89). 
Com a nova política de desenvolvimento e de transportes adotadas pelo Governo Federal, grande parte das ferrovias nacionais encerrou as atividades, especialmente nos trechos onde já se encontrava em funcionamento estradas de rodagem para veículos automotores. Com a construção e asfaltamento da Belém-Brasília, que até Castanhal seguiu paralela ao trajeto da Estrada de Ferro de Bragança, no ano de 1966, pelo Decreto 58.992 de 4 de agosto, a ferrovia foi extinta e teve parte de sua estrutura transferida para outras ferrovias federais ainda em operação.

\section{APONTAMENTOS E CONSIDERAÇÕES FINAIS}

Ao final do século XIX, o Brasil experimentou um crescimento econômico no qual teve parte a fugaz pujança da economia da borracha. Nesse período, a Zona Bragantina, onde também estavam localizados municípios que produziam borracha, foi alvo das experiências de instalação de imigrantes estrangeiros para o desenvolvimento de atividades agrícolas modernas, que produzindo alimentos para o abastecimento do mercado regional contribuiriam para impulsionar, pela diversificação, a economia paraense, cuja atividade mais dinâmica era fundada nos negócios da borracha. Na economia primário-exportadora da borracha, a colonização fomentada pelo governo buscou alocar imigrantes europeus na Zona Bragantina e teve como elemento central a construção de uma ferrovia. O fundamento econômico da ferrovia eram as colônias que se pretendia criar com o fomento à imigração europeia. Os dois elementos - a ferrovia e as colônias de imigrantes europeus - complementavam-se numa expressão da modernidade na zona de produção agrícola do estado do Pará.

Junto ao empreendimento colonizador, justificado pela criação de uma moderna zona produtora de alimentos, a ferrovia foi planejada para encurtar, no tempo, as distâncias que separavam as localidades no entorno de seu curso, fazendo circular, entre Bragança e Belém, a produção dessas localidades. A ferrovia seria, portanto, o projeto estruturante do empreendimento colonizador, pois dinamizaria a ocupação produtiva dos lotes agrícolas, uma vez que a empresa concessionária deveria instalar colonos ao longo de seu eixo, e viabilizaria o transporte mais eficiente da produção de alimentos para o abastecimento das cidades localizadas no eixo da estrada de Bragança e da praça de Belém. Na direção de Bragança seguiriam toda sorte de artigos manufaturados e mercadorias importadas. Na direção de Belém, os produtos da lavoura bragantina. 
Há ainda um elemento interessante para questionar a interpretação sobre a modernidade no Pará e o antagonismo patente entre a riqueza patrocinada pela atividade gomífera e a intenção de dotar o Estado de uma zona produtora de alimentos baseada em técnicas modernas e científicas de produção, servida por uma ferrovia. Com a pujança dos negócios da borracha, o centro comercial de Belém estava à beira do Porto do Pará, onde operavam os vapores transatlânticos que abasteciam a capital com produtos importados da Inglaterra, França, Alemanha, Holanda e para esses destinos exportavam a borracha. Se a ferrovia representava um símbolo da modernidade, a Estação São Brás, símbolo máximo da Estrada de Ferro de Bragança, ficou situada distante da zona portuária de Belém, portanto, deslocada do centro comercial onde imperava os negócios da borracha. Nesse caso, parece que a modernidade no Pará estava mais referida aos vapores transatlânticos que à ferrovia.

O processo histórico da ocupação da Zona Bragantina logrou condições suficientes para a constituição e reprodução socioeconômica de núcleos fundamentados na produção agrícola, abastecedores de si e da capital. Fomentada pelos governos do Pará, a política de colonização com vistas a alocar colonos na Zona Bragantina foi efetivada com a concorrência de dois movimentos: a imigração europeia financiada pelos governos provincial e estadual, realizados no período da construção da estrada de ferro, e o intenso fluxo migratório nordestino, que ocorre paralelo aos investimentos na imigração europeia e com o arrefecimento dos negócios da borracha, quando nova onda de ocupação ocorre, contribuindo também grupos outros de trabalhadores que conseguiram voltar dos seringais. Ainda em relação aos trabalhadores naturais dos estados do Nordeste brasileiro, observou-se que parte deles provavelmente procurou estabelecer morada na Zona Bragantina, uma vez que as populações municipais são significativamente incrementadas a partir da década de 1910. De outro modo, esta observação toma como evidência a Mensagem do Governador Dionísio Ausier Bentes, no ano de 1925 (PARÁ, 1925), que informa sobre a localização desses trabalhadores nas margens da ferrovia. Por outro lado, a maior parte dos colonos estrangeiros preferiu se localizar e empreender atividades econômicas em Belém ou nos centros urbanos dos demais municípios. Cabe lembrar ainda que por se tratar de uma zona que historicamente passou por sucessivos processos de ocupação, outros núcleos produtivos foram formados como resultado dos movimentos de resistência ao trabalho compulsório (LEANDRO, 2010; LEANDRO; SILVA, 2010).

Desse modo, observou-se que a maior parte dos trabalhadores que se dirigiu ou foi dirigido para o estado do Pará e ocupou lotes para a produção agrícola, portanto, que efetivamente promoveu o povoamento e desenvolvimento 
da produção da região de influência da ferrovia, era de origem paraense ou nordestina, em que pese as diversas tentativas de instalação de imigrantes europeus, sobretudo espanhóis e italianos, além da massa portuguesa e dos imigrantes de outras nacionalidades. Aí se colocou uma fração da "Transumância Amazônica” (FURTADO, 2007, p. 189-197).

Apesar da considerável bibliografia que trata de questões sobre as ferrovias no Brasil, são raros os estudos que abordam o tema na Amazônia. É notória a concentração dos estudos nas questões relacionadas aos negócios do café, especialmente porque foi na região de expansão da preciosa rubiácea que tal meio de transporte se desenvolveu com maior profusão, ou melhor, as fronteiras do café e das ferrovias se expandiam mutuamente. São poucas as referências documentais disponíveis aos interessados pela ferrovia da Zona Bragantina. Todavia, os documentos acessados oferecem informações que possibilitam uma abordagem histórica da trajetória percorrida pela Estrada de Ferro de Bragança.

A literatura sobre a questão da colonização da Zona Bragantina tem analisado a experiência como negativa, uma vez que toma em consideração o caso do investimento na imigração europeia. Mesmo apontando a participação de nordestinos, as análises ainda atribuem a eles os fracassos da colonização, haja vista os negócios da borracha atraírem considerável parte da força de trabalho que seguiu o rumo da Amazônia. Há que se reconhecer, portanto, que o florescimento desses núcleos populacionais, objetivado por trabalhadores de distintas origens, conduziu a lavoura bragantina a um nível de produção suficiente para gerar os primeiros lucros da ferrovia, realizados no período entre ao anos de 1916 e 1925, quando os seringais brasileiros já haviam perdido a hegemonia produtiva para as plantações asiáticas.

Com a conclusão da estrada de ferro, inclusive com seus ramais, era de se esperar que sua renda aumentasse, o que de fato ocorreu. Suas despesas também seguiram a mesma trajetória, continuando a elevar os déficits nas operações. Entretanto, gozando o Pará do período áureo da extração da borracha, que iniciou sua fase de declínio na década de 1910, foi a atividade ferroviária uma das responsáveis pelo grande peso aos cofres do tesouro provincial e estadual. Tal peso era suportado em função da renda arrecadada com as exportações de borracha. Aviltadas as rendas com impostos provenientes das exportações de borracha em decorrência da queda geral dos preços, a fazenda pública já não mais dispunha dos recursos necessários para custear os recorrentes déficits operacionais da ferrovia. Dessa maneira, Penteado (1967, p. 127) interpretou que a ferrovia foi "uma doação da borracha do Pará” para a Zona Bragantina. 
Cumpre ainda apontar os impactos ambientais decorrentes desse processo de construção da ferrovia e da ocupação da região. Como zona de histórica ocupação, iniciada ainda no século XVII e intensificada ao final do século XIX, a Zona Bragantina é palco de sucessivos processos de exploração agrícola, transformando a paisagem num mosaico fragmentado de capoeiras e pastagens, sem remanescentes florestais primários (VIEIRA; TOLEDO; ALMEIDA, 2007). Os trens que cortavam a região eram movidos a vapor, e as florestas foram convertidas em lenha para fazer funcionar as locomotivas que transportavam toda sorte de produtos na direção de Belém e de Bragança (ÉGLER, 1961; VIEIRA; TOLEDO; ALMEIDA, 2007). Segundo relatou Augusto Montenegro, o estado do Pará, através da Estrada de Ferro de Bragança, era o maior responsável pela devastação da floresta aí existente (PARÁ, 1903, p. 48).

Com este estudo, buscou-se contribuir para a compreensão do papel da ferrovia na colonização da Zona Bragantina, área de expansão da fronteira agropecuária onde o estado do Pará investiu recursos e esforços na criação de colônias agrícolas para abastecer o mercado de Belém e dinamizar a economia paraense.

Ocupando papel subordinado na economia da borracha, a Zona Bragantina torna-se central no estudo das experiências de colonização europeia no Pará e na formação do mercado de trabalho da capital, haja vista a recolocação dos trabalhadores que para lá se dirigiram após os primeiros anos de trabalho nas colônias.

Desse modo, compreende-se que, enquanto projeto estruturante da ocupação da região, o estudo detalhado da atividade ferroviária na Zona Bragantina auxilia no entendimento do processo de expansão da fronteira agropecuária e na formação do mercado de trabalho regional, uma vez que durante seu período de construção e operação foram atraídos trabalhadores de distintas formações culturais para promover o desenvolvimento da economia paraense, fundada nos negócios da borracha.

\section{REFERÊNCIAS}

ANNUARIO Estatístico do Brazil. $1^{\circ}$ Anno (1908 - 1912). Rio de Janeiro: Typographia da Estatística, 1916.

ARAÚjO, R. A razão na selva: Pombal e a reforma urbana da Amazônia. Camões

- Revista de Letras e Culturas Lusófonas, Lisboa, n.15/16, p. 151-165, jan./ jun., 2003.

Novos Cadernos NAEA •v. 15 n. $2 \cdot$ p. 143-174 • dez. 2012 
BAENA, M. Informações sobre as comarcas da provincia do Pará, organisadas em virtude do Aviso circular do Ministerio da Justiça, de 20 de Setembro de 1883, por Manoel Baena, director da $2^{a}$ secção da secretaria da presidência da mesma provincia. Belém: Typ. Francisco da Costa Junior, 1885. Disponível em: <http://brazil.crl.edu/bsd/bsd/u1022/000027.html>. Acesso em: 10 ago. 2012.

BRASIL. Ministério da Viação e Obras Públicas. Ministro (Francisco Sá). Relatorio apresentado ao Presidente da República dos Estados Unidos do Brasil, Exmo. Sr. Dr. Arthur da Silva Bernardes, pelo Ministro de Estado de Viação e Obras Públicas, Dr. Francisco Sá, anno de 1922. Rio de Janeiro: Imprensa Nacional, 1924. Disponível em: < http://brazil.crl.edu/bsd/bsd/ u2292/>. Acesso em: 5 maio 2011.

Ministro (Francisco Sá). Relatorio apresentado ao Presidente da República dos Estados Unidos do Brasil, Exmo. Sr. Dr. Arthur da Silva Bernardes, pelo Ministro de Estado de Viação e Obras Públicas, Dr. Francisco Sá, anno de 1923. Rio de Janeiro: Imprensa Nacional, 1925. Disponível em: <http://brazil.crl.edu/bsd/bsd/u2293/>. Acesso em: 5 maio 2011.

Ministro (Maurício Joppert da Silva). Relatório apresentado ao excelentíssimo senhor doutor José Linhares, Presidente da República, pelo professor Maurício Joppert da Silva, Ministro de Estado dos Negócios da Viação e Obras Públicas, novembro de 1945 a Janeiro de 1946. Rio de Janeiro, Imprensa Nacional, 1946. Disponível em: < http://brazil.crl.edu/bsd/ bsd/u2299/>. Acesso em: 5 maio 2011.

CASTRO, E. (Org.). Escravos e Senhores de Bragança: documentos históricos do século XIX, região Bragantina, Pará. Belém: UFPA; NAEA, 2006.

COSTA, F. de A. Formação agropecuária da Amazônia: os desafios do desenvolvimento sustentável. Belém: UFPA; NAEA, 2000.

COUTO, J. O Brasil Pombalino. Camões - Revista de Letras e Culturas Lusófonas, Lisboa, n.15/16, p. 151-165, jan./jun., 2003. (Portugal; Instituto Camões)

CRUZ, E. A Estrada de Ferro de Bragança: visão social, econômica e política. Belém: SPVEA, 1955. 
ÉGLER, E. G. A Zona Bragantina no Estado do Pará. Revista Brasileira de Geografia, v. 23, n. 3, p. 527-555, jul./set., 1961.

FURTADO, C. Formação econômica do Brasil. 34. ed. São Paulo: Companhia Editora Nacional, 2007.

IBGE-Instituto Brasileiro de Geografia e Estatística. Ferrovias do Brasil. Rio de Janeiro: IBGE, 1948. Disponível em: <http://biblioteca.ibge.gov.br/ visualizacao/monografias / visualiza_colecao_digital.php?titulo $=$ Ferrovias $\% 20$ do\%20Brasil\%20-\%201946\&link=Ferrovias_do_Brasil_1946>. Acesso em: 19 maio 2011.

Censo 1872. Rio de Janeiro: IBGE. Disponível em: <http:// biblioteca.ibge.gov.br/visualizacao/monografias/visualiza_colecao_digital. php?titulo $=$ Recenseamento $\% 20$ Geral $\% 20 \mathrm{do} \% 20 \mathrm{Brasil} \% 201872 \% 20-\% 20$ Imp $\%$ E 9 rio $\% 20 \mathrm{do} \% 20$ Brazil\&link $=$ Imperio $\% 20 \mathrm{do} \% 20$ Brazil>. Acesso em: 20 abr. 2011.

Censos 1890, 1900, 1920. Rio de Janeiro: IBGE. Disponível em: <http://biblioteca.ibge.gov.br/visualizacao/monografias/GEBIS\%20-\%20RJ/ CD1950/CD_1950_I_Brasil.pdf>.Acesso em: 20 abr. 2011.

Ferrovias do Brasil. Rio de Janeiro: IBGE, 1956. Disponível em: $<$ http://biblioteca.ibge.gov.br/visualizacao/monografias/visualiza_colecao_ digital.php?titulo $=$ Ferrovias $\% 20 \mathrm{do} \% 20$ Brasil\%20-\%201956\&link=Ferrovias_ do_Brasil_1956\#>.Acesso em: 19 maio 2011.

I Centenário das Ferrovias Brasileiras. Rio de Janeiro: IBGE, 1954. Disponível em: <http://biblioteca.ibge.gov.br/visualizacao/monografias/ GEBIS\%20-\%20RJ/centenarioferrovias1954.pdf>. Acesso em: 10 maio 2011.

LEANDRO, L. M. de L. Campesinato e abastecimento na Zona Bragantina (1880-1960). 2010. Dissertação (Mestrado em Planejamento do Desenvolvimento) - Núcleo de Altos Estudos Amazônicos, Universidade Federal do Pará, Belém, 2010.

MACIEL, D. P. A rota Araguaia-Tocantins de comunicação mercantil entre Goiás e Belém do Pará - 1846/1967. In: GOULARTI FILHO, A.; QUEIROZ, P. R. C. Transportes e formação regional: contribuição à história dos transportes no Brasil. Dourados: UFGD, 2011.

MUNIZ, P. Estado do Grão-Pará - Immigração e Colonisação - história e estatística (1616-1916). Belém: Imprensa Official do Estado do Pará, 1916. 
PARÁ. (Província). Presidente (Domingos José Cunha Junior). Relatorio com que o excellentissimo senhor doutor Domingos José da Cunha Junior passou a administração da provincia do Pará ao $3^{\circ}$ vice-presidente, o excellentissimo senhor doutor Guilherme Francisco Cruz, em 31 de dezembro de 1873. Pará: Typ. do Diario do Gram-Pará, 1873. Disponível em: <http://brazil.crl.edu/bsd/bsd/538/>. Acesso em: 15 maio 2011.

Presidente (Francisco Maria Corres de Sá e Benevides). Relatorio apresentado pelo exm. sr. dr. Francisco Maria Corres de Sá e Benevides, presidente da provincia do Pará, á Assembléa Legislativa Provincial na sua sessão solemne de instalação da $20^{\mathrm{a}}$ legislatura, no dia 15 de fevereiro de 1876. Pará, 1876. Disponível em: <http://brazil.crl.edu/bsd/bsd/544/>. Acesso em: 15 maio 2011.

Presidente (Guilherme Francisco Cruz). Relatorio com que o excellentissimo senhor doutor Guilherme Francisco Cruz passou a administração da Provincia do Pará ao excellentissimo senhor doutor Pedro Vicente de Azevedo, em 17 de janeiro de 1874. Pará: Typ. do Diario do Gram-Pará, 1874. Disponível em: < http://brazil.crl.edu/bsd/bsd/u1224/>. Acesso em:15 maio 2011.

Presidente (João Antonio d'Araujo Freitas Henriques). Relatorio com que o exm. snr. conselheiro João Antonio d'Araujo Freitas Henriques passou a administração da provincia do Pará ao exm. snr. desembargador Joaquim da Costa Barradas em 6 de outubro de 1886. Pará: Typ. da Republica, 1891. Disponível em: <http://brazil.crl.edu/bsd/bsd/u1026/>. Acesso em: 15 maio 2011.

Presidente (Joaquim da Costa Barradas). Relatorio com que o exm. sr. desembargador Joaquim da Costa Barradas passou a administração da provincia ao exm. sr. conselheiro coronel Francisco José Cardoso Junior. Pará: Typ. do Diario de Noticias, 1887. Disponível em: < http://brazil.crl.edu/ bsd/bsd/560/>. Acesso em: 15 maio 2011.

Presidente (José Coelho da Gama e Abreu). Falla com que o excellentissimo senhor doutor José Coelho da Gama e Abreu, presidente da provincia, abriu a $2^{\mathrm{a}}$ sessão da $21^{\mathrm{a}}$ legislatura da Assembléa Legislativa da provincia do Gram-Pará, em 16 de junho de 1879. Pará, 1879. Disponível em: <http://brazil.crl.edu/bsd/bsd/549/>. Acesso em: 15 maio 2011. 
Presidente (José da Gama Malcher). Relatorio com que o exm. sr. Dr. José da Gama Malcher, $1^{\circ}$ vice-presidente, passou a administração da provincia ao exm. sr. Dr. João Capistrano Bandeira de Mello Filho em 9 de março de 1878. Pará: Typ. Guttemberg, 1878. Disponível em: < http://brazil. crl.edu/bsd/bsd/548/>. Acesso em: 20 maio 2011.

PARÁ. (Província). Presidente (Miguel José d'Almeida Pernambuco). Relatorio com que o exm. sr. dr. Miguel José d'Almeida Pernambuco, presidente da provincia do Pará passou a administração da mesma ao vice presidente da provincia exm. sr. dr. João Polycarpo dos Santos Campos em 18 de março de 1889. Pará: Typ. de A. Fructuoso da Costa, 1889. Disponível em: <http:// brazil.crl.edu/bsd/bsd/u1028/>. Acesso em: 20 maio 2011.

Presidente (Pedro Vicente de Azevedo). Relatorio apresentado ao exm. senr. Dr. Francisco Maria Corres de Sá e Benevides pelo exm. senr. Dr. Pedro Vicente de Azevedo, por occasião de passar-lhe a administração da provincia do Pará, no dia 17 de janeiro de 1875. Pará, 1875. Disponível em: <http://brazil.crl.edu/bsd/bsd/543/>. Acesso em: 20 maio 2011.

Presidente (Rufino Enéas Gustavo Galvão, Barão de Maracajú). Falla com que o exm. sr. general Barão de Maracajú abrio a $2^{a}$ sessão da $23^{a}$ legislatura da Assembléa Legislativa da Provincia do Pará em 15 de fevereiro de 1883. Pará: Typ. do Jornal da Tarde,1883. Disponível em: < http:// brazil.crl.edu/bsd/bsd/554/>. Acesso em: 20 maio 2011.

PARÁ. Governo do Estado. Governador (Augusto Montenegro). Mensagem dirigida em 7 de setembro de 1902 ao congresso legislativo do Pará pelo dr. Augusto Montenegro, governador do estado. Belém: Imprensa Official, 1902. Disponível em: <http://brazil.crl.edu/bsd/bsd/u2436/>. Acesso em: 12 maio 2011.

Governador (Augusto Montenegro). Mensagem dirigida em 7 de setembro de 1903 ao congresso legislativo do Pará pelo dr. Augusto Montenegro, governador do estado. Belém: Imprensa Official, 1903. Disponível em: < http://brazil.crl.edu/bsd/bsd/u2437/>. Acesso em: 12 maio 2011.

Governador (Dionysio Ausier Bentes). Mensagem apresentada ao Congresso Legislativo do Estado, em sessão solenne de abertura da $2^{a}$ reunião de sua $12^{a}$ legislatura, a 7 de setembro de 1925, pelo governador do Estado, Dr. Dionysio Ausier Bentes.[ s.l.], 1925. Disponível em: <http:// brazil.crl.edu/bsd/bsd/u1046/>. Acesso em: 5 fev. 2010 
PARÁ. Governo do Estado. Governador (Dionysio Ausier Bentes). Mensagem apresentada ao Congresso Legislativo do Estado do Pará em sessão solenne da $3^{\text {a }}$ reunião de sua $12^{a}$ legislatura a 7 de Setembro de 1926 , pelo governador do estado Dr. Dionysio Ausier Bentes. Pará: Officinas Graphicas do Instituto Lauro Sodré, 1926. Disponível em: <http://brazil.crl.edu/bsd/ bsd/u1047/>. Acesso em: 15 maio 2011.

Governador (Duarte Huet de Bacellar Pinto Guedes). Relatorio com que o capitão tenente Duarte Huet de Bacellar Pinto Guedes passou a administração do estado do Pará em 24 de junho de 1891 ao governador dr. Lauro Sodré, eleito pelo conselho constituinte em 23 do mesmo mez. Belém: Typ do Diario Oficial, 1891. Disponível em: < http://brazil.crl.edu/bsd/ bsd/u2416/>. Acesso em: 15 maio 2011.

Governador (Enéas Martins). Mensagem dirigida em 1 de agosto de 1915 ao congresso legislativo do Pará pelo dr. Enéas Martins, governador do estado. Belém: Imprensa Official do Estado do Pará, 1915. Disponível em: <http://brazil.crl.edu/bsd/bsd/u1035/>. Acesso em: 15 maio 2011.

Governador (Enéas Martins). Mensagem dirigida em 1 de agosto de 1916 ao congresso legislativo do Pará pelo dr. Enéas Martins, governador do estado. Belém: Imprensa Official do Estado do Pará, 1916. Disponível em: <http://brazil.crl.edu/bsd/bsd/u1036/>. Acesso em: 15 maio 2011.

Governador (João Antônio Luiz Coelho). Mensagem dirigida em 7 de Setembro de 1910 ao Congresso Legislativo do Pará, pelo Dr. João Antônio Luiz Coelho. Belém: Imprensa Official do Estado do Pará, 1910. Disponível em: <http://brazil.crl.edu/bsd/bsd/u2444>. Acesso em: 18 maio 2011.

Governador (João Antônio Luiz Coelho). Mensagem dirigida em 7 de Setembro de 1911 ao Congresso Legislativo do Pará, pelo Dr. João Antônio Luiz Coelho. Belém: Imprensa Official do Estado do Pará, 1911. Disponível em: <http://brazil.crl.edu/bsd/bsd/u1031/>. Acesso em: 12 maio 2011.

Governador (José Paes de Carvalho). Mensagem dirigida ao congresso do estado do Pará pelo dr. José Paes de Carvalho, governador do estado, em 15 de abril de 1898 apresentando proposta de orçamento da receita e despesa para o exercicio 1898-1899. Belém: Typ. do Diario Official, 1898. Disponível em: <http://brazil.crl.edu/bsd/bsd/u2428/>. Acesso em: 12 maio 2011. 
PARÁ. Governo do Estado. Governador (Lauro Sodré). Mensagem dirigida ao congresso do estado do Pará pelo dr. Lauro Sodré, governador do estado, ao expirar seu mandato, no dia $1^{\circ}$ de fevereiro de 1897. Pará: Diario Official, 1897. Disponível em: <http://brazil.crl.edu/bsd/bsd/u2423/>. Acesso em: 15 maio 2011.

Governador (Lauro Sodré). Mensagem dirigida em 1 de agosto de 1917 ao Congresso Legislativo do Pará pelo dr. Lauro Sodré, governador do Pará. Belém: Imprensa Official do Estado, 1917. Disponível em <http:// brazil.crl.edu/bsd/bsd/u1038/>. Acesso em: 15 maio 2011.

PARÁ. Governo do Estado. 1899 (José Paes de Carvalho). Álbum do Pará em 1899: na administração de sua excia. o sr. dr. José Paes de Carvalho. Belém: Felipe Augusto Fidanza, 1899.

PARÁ. Governo do Estado, 1901-1909 (Augusto Montenegro). Álbum do Estado do Pará: oito annos de governo. Paris: Chaponet, 1908.

PENTEADO, A. R. Problemas de Colonização e de Uso da Terra na Região Bragantina do Estado do Pará. Belém: UFPA, 1967. 2 v.

PRADO JÚNIOR, C. História econômica do Brasil. São Paulo: Brasiliense, 1945.

VIEIRA, F. Os caminhos ferroviários brasileiros. In: I centenário das ferrovias brasileiras. Rio de Janeiro: IBGE, 1954. (Diversos autores).

VIEIRA, I. C. G.; TOLEDO, P. M. de; ALMEIDA, A. Análise das modificações da paisagem da região bragantina, no Pará, integrando diferentes escalas de tempo. Ciência e Cultura, São Paulo, v. 59, n. 3, p. 27-30, 2007. 